\title{
Tami Blumenfield and Helaine Silverman (eds), Cultural Heritage Politics in China,
}

New York, Springer, 2013, 297 pp.

Katiana Le Mentec

Translator. N. Jayaram

\section{OpenEdition}

1 Journals

Electronic version

URL: http://journals.openedition.org/chinaperspectives/6546

DOI: 10.4000/chinaperspectives.6546

ISSN: 1996-4617

\section{Publisher}

Centre d'étude français sur la Chine contemporaine

\section{Printed version}

Date of publication: 1 September 2014

Number of pages: 61-63

ISSN: 2070-3449

\section{Electronic reference}

Katiana Le Mentec, «Tami Blumenfield and Helaine Silverman (eds), Cultural Heritage Politics in China, », China Perspectives [Online], 2014/3 | 2014, Online since 01 January 2017, connection on 23

September 2020. URL : http://journals.openedition.org/chinaperspectives/6546 ; DOI : https://doi.org/ 10.4000/chinaperspectives.6546

\section{This text was automatically generated on 23 September 2020}

(c) All rights reserved 


\section{Tami Blumenfield and Helaine Silverman (eds), Cultural Heritage Politics in China,}

New York, Springer, 2013, 297 pp.

\section{Katiana Le Mentec}

Translation : N. Jayaram

1 Tami Blumenfield, a filmmaker and ethnologist who has focused on the Na people of Yunnan, teamed up with Helaine Silverman, an anthropologist specialising in Peruvian archaeology and cultural policies, to edit this volume on China's cultural heritage. The theme echoes an inescapable reality of the past decades and the subject of innumerable academic studies. With 15 contributions, the editors offer a discussion of the way in which heritage is protected and administered in China, by whom, for what purpose, and with what results. Their conclusion - it is a complex reality (p. 18) resonates with the views of the book's contributors.

2 The chapters decipher acts of heritage - Laura Jane Smith's concept cited by Gary Sigley (p. 239) - concerning natural sites, villages,

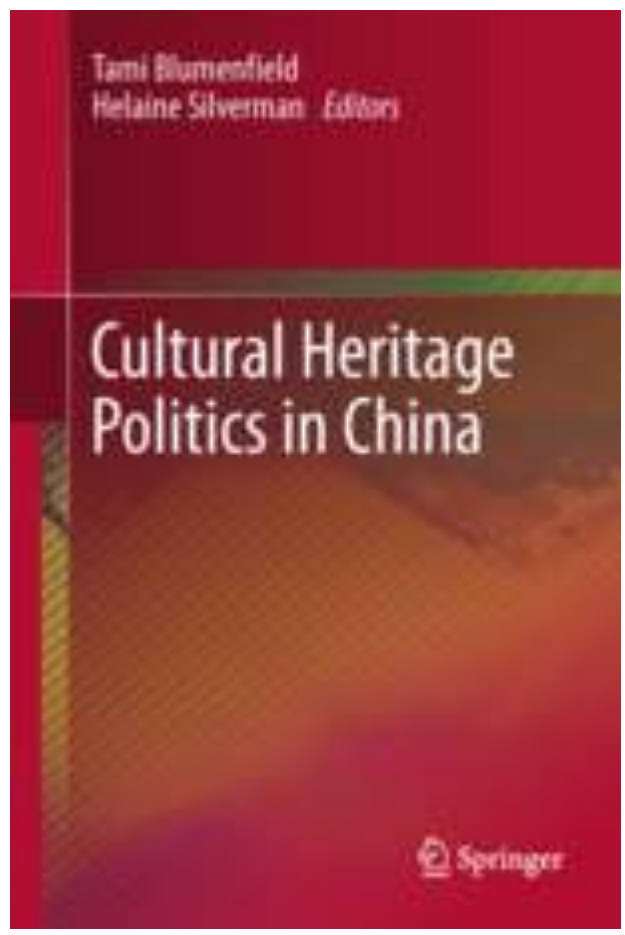
worship places (local, Daoist, Buddhist), ritual practices, trade routes (such as for tea), or excavations. Each author presents a special configuration, a combination of actors, ways of action, and issues. The multiple situations offer a glimpse of the variety of personages engaged in the heritage protection process and in 
tourism projects generally: villagers (Han or ethnic minorities), local elites, members of religious communities, small businesses, leaders of major companies, officials (national, regional, and local), UNESCO representatives, and tourists (Chinese and foreign). The authors examine their attempts, motivations, and interests as well as monopolies, conflicts, mobilisations, negotiations, strategies, and competitions.

The book presents a vast palette of heritage projects. William Nitzky's analysis focuses on UNESCO-initiated participative projects in which the authorities have trouble accepting community participation. Curtis Ashton examines innovative initiatives by administrators of a temple-museum in Beijing caught up in municipal politics during the Olympic Games. Heather Peters retraces the failures UNESCO's recommendations met with at Lijiang in Yunnan Province and the reasons for the Naxi people's gradual migration from the old city. Zhu Yujie and Li Na look into the leeway of local actors in the sacred Emei Mountain, a World Heritage and mass tourism site. Liu Tzu-kai sheds light on a museologist's work on heritage preservation in her native Wa minority village in remote Yunnan. One of the book's great strengths is that the authors narrate the history of sites and the adoption and evolution of cultural policies. Zhao Wei, for instance, analyses centuries of people's enrolment in a local cult as well as ritual and economic practices linked to its pilgrimage site, the heritage designation process, and relocation of villages. The contexts are explained through various angles. For instance, Su Xiaobo concentrates on small Han businessmen's role in mass tourism in Lijiang's old city.

Well known issues (economic, ideological, identity; national, regional, local) surrounding heritage sites inform the volume touching on all contexts. Three chapters deal with geopolitical issues. Gary Sigley and Zhou Yongming show how the Yunnan authorities and those in one of the border villages rely on ancient international routes - deemed heritage sites - to promote a new identity brand in order to socially reconfigure their space. From "peripheral sites" they are presented as "bridges" with the outside world allowing them to position themselves at the "centre" of a globalised China. Jeff Adams offers a fascinating account of several issues relating to submerged heritage, which has attracted massive national investment. He sees them as genuine instruments of soft power on the global chessboard: the submerged wrecks are presented as a vector of national pride (highlighting both Chinese civilisation's maritime golden age and its current technical capacity to work under water) as well as a symbolic and legal means of pressure in the context of sovereignty disputes over islands in the South China Sea and a diplomatic tool to illustrate ancient cultural links with countries being courted (such as Kenya).

What characterises the book is undoubtedly its profound heterogeneity. The authors are drawn from diverse fields - anthropology, law, geography, architecture, Sinology, heritage studies, and gender studies - and some of them act as experts or consultants for public or private heritage projects. The ethnographies are of unequal depth. While some authors narrate, sometimes forcefully, the details of their methodology and paint vivid portraits of people encountered, others dispense with them in favour of a major thematic or theoretical contextualisation. Nitzky offers synthetic digressions - didactic, of course - alongside rare and fascinating cases (such as cultural mapping) rather too quickly reviewed. The degree of argumentation and theorisation in different chapters in the book also varies considerably. At the book's outset, Tang Zijun declares that the current legislative system does not favour sustained development of China's heritage resources. The reader - keen to understand the legal workings - is left clueless while faced with a text that declares but fails to explain the flow of legislation, the absence of rules, and regulations and ignores the possible inter- 
provincial distinctions. Margaret Swain engages in a highly specialised discussion on cosmopolitanism to explain her theoretical approach to the existence of the Han government's own vision of cosmopolitanism. She relies on two classical Chinese concepts (tianxia and shijie) - vernacular terms that numerous actors use these days - and which she elevates to the category of scientific analysis. She then illustrates her proposition through projects deemed eco-touristic implicating minorities in Yunnan - whose description may provoke reactions among ethnologists familiar with the region and dealing with local realities in less idealistic and more nuanced manner. Meanwhile, contributors have a general tendency (exemplified by Liu Tzu-kai) to apply notions and theories fashioned in other cultural spheres without saying so. While the mobilisation of inescapable references in matters of cultural policies is most useful to readers seeking an overall view of the subject, this way of writing nevertheless poses the question of the relevance of the analyses. If neither contextualised nor well argued, the importation of theories hardly convinces specialists. Zhou Yongming rightly points out that concepts such as "globalisation" are not transposable (p. 249).

6 The disparate chapters have been rather artificially arranged. Indeed, the parts group texts according to the types of heritage discussed (listed/not listed by UNESCO, museum or route), whereas the reality described does not quite adhere to such divisions. Contrary to the impression the title might give, the book is not intended as a comprehensive, overarching, or orderly presentation of the theme. The collection of texts, each offering localised information, comes across as a voyage during which the reader gleans snippets of a vast subject. The introduction gives a broad outline of the context for the non-specialist, stressing the case of minorities and political issues. Gradually the neophyte learns of the existence of heritage protection bureaux, some laws and administrative workings. The compartmentalised chapters show numerous repetitions. Those seeking a general reflection on heritage policies in China might wish the editors had attempted a deeper approach by letting the texts interact, thereby infusing dynamism to the book as a whole.

7 It would also have been judicious to identify and discuss the contributors' viewpoints in the introduction. Most of them are committed to heritage protection, favouring the UNESCO model or a solution to improve conservation following the criteria of that international institution. For instance, Zhou Yongming and Li Na deplore the fact that protection is oriented towards economic benefit and suggest the setting up of regulatory agencies. The book is replete with albeit discretely stated value judgements and presumptions alongside feelings that are never cleared up. Scientific readers might note this absence of distance and deem it a weakness that could lead to truncated or even biased argumentation. Zhao Wei criticises the lack of authenticity of a temple rebuilt a few metres from the old one and says the latter ought to have been subject to a protection programme. The book's editors likewise voice concerns in the introduction over the "pattern of razing buildings" (p. 19). There is no mention of the practice in China of the faithful periodically destroying temples to rebuild them using new materials so as to more effectively honour the deities. Just as Chinese conceptions are glossed over in the book, the grading and conservation of vestiges prior to the UNESCO conventions are simply ignored, although they have been practised for centuries in different forms. In her highly didactic work on museum policies (Museums in China: The Politics of Representation After Mao, Boydell \& Brewer, 2014), Marzia Varutti takes note of the antiquity of indigenous measures and conceptions. They appear in numerous local accounts, for instance, in Yunyang (Chongqing), where historical annals published in 1541 identify and grade vestiges of the past (guji) and where headstones mentions funds set aside for periodic renovations. 
These examples illustrate the authors' positions with regard to heritage protection, taken at face value and considered an ethnocentric objective - without questioning or comparing with possible indigenous equivalents. Su Xiaobo, who has worked on the notion of authenticity, briefly touches on the subject but only in the chapter's conclusion. The approach chosen in the book inevitably leads to the obliteration of two basic actors. First, UNESCO, its officials and consultants with their own motivations, are engaged in strategies and develop modes of action. Second, the researcher - it is clear from a reading of this book - is often implicated in local issues. It is only the chapters by Liu Tsu-kai and Gary Sigley that truly question the values these actors attribute to heritage and analyse their role. Epistemological reflection on the role of researchers - especially ethnologists - in the context of protection of cultural practices has, however, been studied in depth in other cultural spheres such as in the Americas. Stevan Harrell's text implicitly notes these defects. Happily, his concluding chapter in the book places indigenous conceptions at the centre of the discussion. He shows that due to numerous local and international issues, cultural protection practices in China follow Western characteristics (a model favouring a certain authenticity) and Chinese ones (absence of distinction between what is old, preserved, and "authentic" and what is new, rebuilt, and copied). The reader (or could it be the contributors?) are invited to take a step back and consider the observed practices and sites as cultural products. As for the question of their authenticity - which so offends Western positions faced with abundant reworkings in China - the author prefers to consider the value attached to them by the Chinese themselves, who are the actors and participants.

Despite the criticisms made above, this book will be of much use to informed readers: researchers, students, those new to the Chinese world, consultants, and those passionate about heritage protection. The contributions offer an exceedingly rich panorama of multiple situations observable in contemporary China and give a good account of complex local realities, going beyond mere legislations and rules that appear uniform. Containing some original gems and detailed ethnographic case studies, the book completes academic work in the domain and opens up a multitude of research avenues: museum-temples, cultural mappingprojects, study of narratives proposed by Cornelius Holtorf and suggested in the introduction (p. 19), or even indigenous conceptions and practices linked to heritage and conservation (those of the Han, the Naxi, or Tibetans - not taken as homogenous groups - but also the Japanese, the Fon people, and the Aymaras, for example) and their interactions with a globalised Western model. The book brings out the dynamism of this theme and the need to pursue this line of reflection. Those seeking to further pursue the issue of heritage and museums in China might wish to consult two recent works: the special issue on "China: the State at the Museum" of the journal Gradhiva in 2012, and Kirk A. Denton's Exhibiting the Past: Historical Memory and the Politics of Museums in Postsocialist China (University of Hawai'i Press, 2014). 


\section{AUTHORS}

\section{KATIANA LE MENTEC}

Katiana Le Mentec is a visiting scholar and a Fernand Braudel post-doctoral fellow at the University of York (UK) and Young Research Associate at the Centre for Modern and Contemporary Chinese Studies at the EHESS (School for Advanced Studies in Social Sciences), Paris (katianalementec@yahoo.fr). 